JOGOS ELETRÔNICOS

\section{FRONTEIRAS ENTRE FICÇÃO E REALISMO}

Do viciante Hero do saudoso Atari à crueldade chocante de um Grand Theft Auto V, os jogos para computadores celulares e videogames estão cada vez mais realistas. Os últimos desenvolvimentos, no entanto, têm colocado a questão da distinção entre jogo e realidade em outro plano, trazendo não apenas a reprodução do mundo que habitamos para o console do videogame, mas o próprio jogo ou alguns de seus elementos para as ruas da cidade.

Uma das tecnologias responsáveis por essa interpenetração leva o nome de realidade aumentada ou realidade expandida. Ela permite que certas projeções sejam mostradas na tela quando, por exemplo, o GPS identifica que o usuário está em um determinado ponto ou quando a câmera do celular identifica determinado código. No caso dos jogos que se utilizam de realidade aumentada, o jogador élevado a deslocar-se geograficamente para um lugar para conseguir realizar uma tarefa. Com isso, na tela do celular, um novo mundo se abre, se soma ou se expande.

Um dos jogos mais notáveis que usam os recursos do telefone celular para brincar com a realidade aumentada é o Ingress, do Google, feito para a plataforma Android. Ele divide os jogadores em duas facçôes cujo objetivo é controlar territorialmente o planeta. Esse controle se dá pela construção e ligação entre portais, lugares em que uma misteriosa energia alienígena se manifestaria. Para criar um portal é necessário fotografar lugares históricos, turísticos ou de aglomeração de pessoas (igrejas, praças, prédios históricos, grafites, obras de arte espalhadas em lugares públicos da cidade).

FERRAMENTA EDUCACIONAL Alguns pesquisadores têm apontado o Ingress como um curioso experimento cujos princípios podem ser utilizados para se pensar desde novos modelos educacionais até políticas de conservação ambiental. Lee Yik Sheng, no artigo "Modelando o aprendizado em Ingress (o jogo social de realidade aumentada do Google" (no original, "Modelling learning from ingress (Google's augmented reality social game"), compara a jogabilidade do aplicativo a elementos utilizados nos MOOCs (Cursos Online Abertos e Massivos, na sigla em inglês), em que o aprendizado é feito de forma coletiva, com os alunos ensinando uns aos outros e, para isso, utilizando meios de comunicação online, como fóruns e grupos de discussão em redes sociais. Já Chris Sandbrook, William M. Adams, Bruno Monteferri, no artigo "Jogos digitais e a conservação da biodiversidade" (no original, "Digital games and biodiversity conservation) falam no potencial das práticas de gameficação para a preservação ambiental. Gameficação é um neologismo criado para o uso de elementos dos jogos, como a competição a partir de certas regras e a soma de pontos, para outras atividades não diretamente relacionadas, como fazer exercícios, compras ou mesmo outros tipos de trabalho convencionais. Nesse sentido, o Ingress seria um jogo de realidade mista, não contido somente num ambiente virtual nem no mundo físico. Segundo os autores, a gameficação poderia ser usada na conservação ambiental para educação e mudança de comportamentos; levantamento de recursos e para a promoção de pesquisas, monitoramento e planejamento.

MAPEAMENTO ON LINE De fato, o Ingress parece que já está sendo usado pelo Google para, de alguma forma, colocar seus jogadores para trabalhar, ainda que se divertindo, na coleta de informaçôes que se tornam valiosas nas mãos da empresa. "Esse é o jeito clássico do Google", declarou Blair MacIntyre, diretora do Laboratório de Realidade Aumentada do Instituto Georgia Tech, nos Estados Unidos, à revista New Scientist: "Eles conseguem garimpar informaçōes sobre novos monumentos e isso na verdade os ajuda a gerar resultados mais interessantes, pois isso é o que as pessoas do local dizem que é o que há de mais interessante". Um exame rápido sobre os pontos mapeados pelos jogadores comprova a declaração da pesquisadora. Mesmo as cidades médias brasileiras já têm mapeados pelos jogadores não somente os monumentos mais óbvios, mas também atraçōes turísticas e grafites pintados recentemente, o que oferece à empresa um interessante banco de dados, muito difícil e caro de ser construído de maneira profissionalizada. 
O jogo também tem sido utilizado como chamariz para pontos comerciais. Nos Estados Unidos, a Google já fechou contrato com a loja de sucos Jamba Juice, transformando diversos estabelecimentos físicos da cadeia de sucos em locais de interesses para os jogadores.

\section{WATCH DOGS E A VIGILÂNCIA UBÍQUA}

Mas se alguns jogos usam camadas de ficção para explorar um trabalho real, outros abusam do realismo para descortinar esse mundo de interconexão informacional e vigilância por toda parte. Watch Dogs, da Ubisoft, que roda nas principais plataformas de videogames, coloca na tela um mapa detalhado da cidade de Chicago (EUA), e é estrelado por um personagem capaz de hackear o sofisticadíssimo sistema de informação da cidade para realizar suas missões. Em 2003, ocorreu um apagão nos Estados Unidos e no Canadá e o jogo usa esse fato para ficcionalizar a criação de um supercomputador que controlaria todo o sistema informacional da cidade, interligando as câmeras de vigilância e caixas eletrônicos espalhados pelas ruas ao sistema de semáforos.

Watch Dogs é um ótimo exemplo de jogo eletrônico que funciona do mesmo modo que qualquer obra artística ou literária. Por meio de uma história aparentemente ficcional a obra descreve um mundo controlado pela vigilância informacional, em que os dados pessoais e as atividades interligadas em rede se tornaram fonte de valor financeiro e meio privilegiado de contato entre as pessoas.

Rafael Evangelista
NEUROCIÊNCIA

\section{DESVENDANDO OS MECANISMOS DO PRAZER DE OUVIR MÚSICA}

Sentimos um imenso prazer quando escutamos músicas das quais gostamos. Mas como nosso cérebro decide se gostou ou não de uma música inédita a ponto de pagar por ela? A música nos proporciona uma ampla gama de emoçôes. É capaz de excitar ou relaxar, alegrar ou deprimir, motivar ou irritar. Dificilmente conseguimos ser indiferentes a uma canção. A capacidade de fazer e ouvir música é exclusiva da espécie humana. A música está presente em todas as culturas do mundo e estudos indicam que ela precede a linguagem.

OS EFEITOS DA MÚSICA Podemos ouvir uma melodia e ela ser interpretada apenas como um ruído dentre tantos outros. Entretanto, quando escutamos uma canção que nos dá prazer criamos empatia. "Se estabelecemos sincronia com uma determinada música, ocorre um tipo de recompensa afetivo-emocional", explica Mauro Muszkat, músico e médico neurologista, coordenador do Núcleo de Atendimento Neuropsicológico Infantil Interdisciplinar (Nani), do Departamento de Psicobiologia da Universidade Federal de São Paulo (Unifesp). "Neste estado ocorrem respostas periféricas da pele, tais como ereção do pelo, podendo levar a uma vasoconstrição e tremores. Além disso, há períodos da música nos quais as pessoas atingem outro estado de consciência por conta do envolvimento intenso com a melodia", complementa. Ainda segundo ele, ocorre uma integração de vários circuitos emocionais, cognitivos e perceptuais levando o ouvinte a um estado de alegria instantânea.

ATIVIDADE CEREBRAL Háalguns fatores individuais que devem ser considerados ao analisarmos os sentimentos causados por um determinado som. Músicas diferentes levam a ativações neurais diversas, proporcionando, assim, reações diferentes em pessoas distintas. A idade, personalidade, cultura e formação musical, influenciam muito o chamado gosto musical de cada indivíduo.

Em 2009, um grupo de neurocientistas da Universidade de Columbia realizou um experimento com o escritor Oliver Sacks, no qual ele ouviu o compositor alemão Johann Sebastian Bach, de quem é fã desde a infância, e Ludwig van Beethoven, de quem gosta pouco. Sacks teve suas atividades cerebrais mensuradas por um aparelho de ressonância enquanto ouvia trechos de músicas dos dois artistas. Seu cérebro foi muito mais ativado após escutar Bach do que Beethoven. A amígdala, essencial para processar emoções e responsável pela formação da associação entre estímulos e recompensas, foi a região mais ativada.

Quando submetido a outro experimento, no qual escutava uma música de quem não sabia a autoria, Beethoven ou Bach, Sacks foi capaz de distingui-la inconscientemente, e novamente seu cérebro apresentou 